\title{
Sistem Personalisasi E-Learning Berorientasi Felder Silverman Learning Style Model Pada Mata Pelajaran Teknik Pengambilan Gambar
}

\author{
Gusti Nyoman Pardomuan \\ Program Studi Teknologi Pembelajaran, Pascasarjana, Universitas Pendidikan Ganesha \\ domuzx@gmail.com
}

Ni Nyoman Parwati

Program Studi Teknologi Pembelajaran, Pascasarjana,Universitas Pendidikan Ganesha parwatimat@gmail.com

Ketut Agustini

Program Studi Teknologi Pembelajaran, Pascasarjana, Universitas Pendidikan Ganesha ketutagustini@undiksha.ac.id

\begin{tabular}{l} 
A R T I C L E I N F O \\
\hline Article history: \\
1 Januari 2020 Received in \\
revised form \\
30 Mei 2020 \\
Accepted 30 Juni 2020 \\
Available online \\
15 Juli 2020 \\
Kata Kunci: \\
e-learning, felder silverman \\
learning style model, teknik \\
pengambilan gambar, hasil \\
belajar. \\
Keywords: \\
e-learning, felder silverman \\
learning style model, shooting \\
technique, learning achievements.
\end{tabular}

\begin{abstract}
A B S T R A K
Perkembangan e-learning saat ini terus semakin innovative, namun media e-learning masa kini kurang memperhatikan karakteristik belajar siswa salah satunya karakteristik gaya belajar menjadi suatu masalah belajar baru bagi peserta didik. Maka dari itu dikembangkan $E$ learning yang mampu mengakomodasi gaya belajar siswa sehingga menjadi semakin adaptif (menyesuaikan) dengan adanya personalisasi e-learning yang dapat mendeteksi karakteristik dan kebutuhan individu dari siswa. Penelitian ini bertujuan menciptakan sebuah personalisasi e-learning untuk lingkungan sekolah menengah kejuruan, Penelitian ini bertujuan untuk mengembangkan sebuah media ajar berupa system perosonalisasi e-learning berorientasi
\end{abstract} Felder Silverman Learning Style Model (FSLSM) pada siswa kelas XI jurusan multimedia di SMK Negeri 1 Sukasada yang menjadi salah satu solusi untuk meningkatkan hasil belajar siswa. Metode penelitian yang digunakan adalah metode pengembangan ADDIE. Subjek dalam penelitian ini adalah ahli isi pembelajaran, ahli media pembelajaran, ahli desain pembelajaran, siswa perorangan, siswa kelompok kecil, dan siswa dalam uji coba lapangan. Variabel yang diteliti dalam penelitian ini adalah e-learning berorientasi FSLSM dan hasil belajar siswa kelas XI Multimedia di SMK Negeri 1 Sukasada. Data penelitian dikumpulkan dengan menggunakan instrumen wawancara lisan, kuisioner, dan tes hasil belajar. Data hasil penelitian dianalisis secara deskriptif kualitatif, deskriptif kuantitatif, dan statistik inferensial (uji-t). Hasil analisis data menunjukkan bahwa telah berhasil dirancang sebuah system personalisasi $e$-learning berorientasi FSLSM untuk pembelajaran teknik pengambilan gambar dan telah valid untuk digunakan. Hasil analisis statistik inferensial menunjukkan bahwa e-learning berorientasi FSLSM efektif untuk meningkatkan hasil belajar siswa.

\section{A B S T R A K}

The development of e-learning at this time continues to be increasingly innovative, but today's e-learning media pay less attention to the characteristics of students who learn the wrong learning styles into new learning problems for students. Therefore, E-learning is developed that is able to accommodate student learning styles so that it 
becomes more adaptive (customize) with the personalization of e-learning that can facilitate individual characteristics and needs of students.This research aims to develop a media in the form of e-learning personalize system oriented to Learning and Learning in the class XI students multimedia majors in SMK Negeri 1 Sukasada which became one of the solutions to improve student learning outcomes. The research method used is the development method of ADDIE. Subjects in this study were learning experts, instructional media experts, instructional designers, individual students, small group students, and students in field trials. The variables studied in this research are FSLSM oriented e-learning and student learning result of class XI Multimedia at SMK Negeri 1 Sukasada. Research data were collected using oral interview instruments, questionnaires, and learning result tests. The data of the research were analyzed descriptively qualitative, quantitative descriptive, and inferential statistics ( $t$-test). The result of data analysis that has been successfully used for the learning technique of shooting and has been valid for use. Results of inferential statistical analysis showing e-learning orientation of FSLSM effective to improve student learning outcomes.

\section{PENDAHULUAN}

Penggunan media pembelajaran berupa e-learning masa kini sudah semakin inovatif, bahkan tidak sedikit media pembelajaran di era sekarang ini sudah dikemas dalam bentuk virtual. Namun dari semua kecanggihan e-learning, e-learning masih belum mampu mengukur tingkat krakteristik pebelajar (Mothukuri et al., 2017). Salah satunya karakteristik gaya belajar peserta didik. Masing-masing peserta didik atau siswa sebagai individu dan subjek belajar memiliki karakteristik atau ciri-ciri sendiri. Kondisi atau keadaan yang terdapat pada masing-masing siswa dapat mempengaruhi bagaimana proses belajar siswa tersebut. Dengan kondisi peserta yang mendukung maka pembelajaran tentu dapat dilakukan dengan lebih baik, sebaliknya pula dengan karakteristik yang lemah maka dapat menjadi hambatan dalam proses belajar mengajar. Dalam upaya mencapai tujuan pembelajaran tersebut, maka memperhatikan dan mempertimbangkan karakteristik siswa menjadi sebuah keharusan. Sebab hasil belajar yang diperoleh siswa dipengaruhi oleh strategi pembelajaran yang diterapkan dan karakteristik siswa (Slavin, 1977).

Media e-learning pada penelitian ini dibuat secara adaptif yaitu sistem e-learning mampu menyesuaikan secara otomatis kepada pengguna berdasarkan asumsi tentang pengguna tersebut (Cronin, 2012). Proses adaptasi dalam sistem e-learning dapat diilustrasikan seperti dalam gambar berikut.

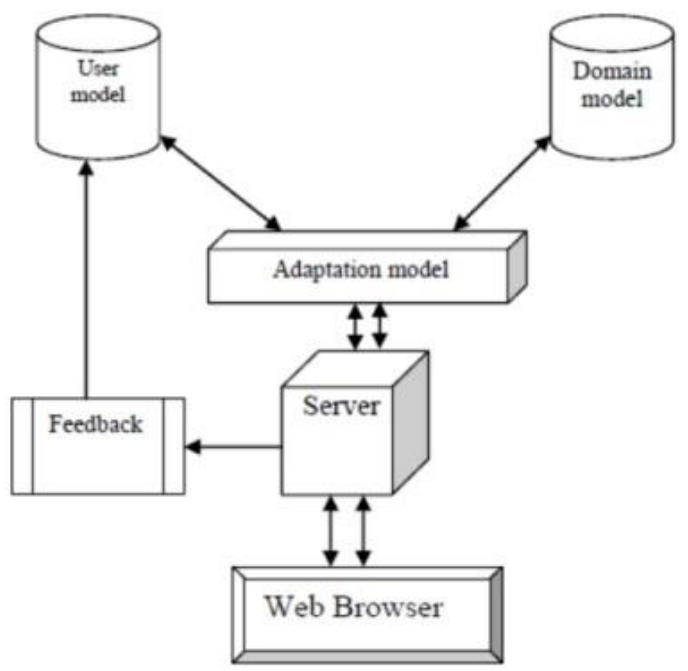

Gambar 1. System Arsitektur AdeLe adaptasi (Agustini, 2017) 
SMK sebagai salah satu lembaga pendidikan kejuruan perlu membekali siswa dan lulusannya dengan keterampilan yang memadai termasuk kompetensi ICT. Tuntutan yang harus dilaksanakan sekolah dalam pelaksanaan proses pembelajaran yang memanfaatkan teknologi informasi dan komunikasi menghadapi berbagai kendala yang tidak sederhana. Masalah utama yang seringkali dihadapi oleh pihak sekolah dan guru adalah keterbatasan sarana dan prasarana, sumber daya manusia dan sumber belajar.

Siswa memiliki cara yang berbeda untuk belajar. siswa dengan preferensi (disukai) yang kuat untuk gaya belajar tertentu dapat memiliki kesulitan dalam belajar jika cara mengajar tidak sesuai dengan gaya belajar mereka, sehingga siswa yang gaya belajar tidak didukung oleh lingkungan belajar mungkin mengalami masalah dalam proses pembelajaran. Idealnya setiap pelajar mendapat perlakuan yang berbeda-beda sesuai dengan gaya belajarnya masing-masing. Akan tetapi, tentu tidak mudah bagi para pengajar untuk dapat menyesuaikan cara mengajarnya dengan kebutuhan murid yang berbeda-beda. Cara mengajar tiap pengajar mungkin cocok untuk sebagian pelajar dengan gaya belajar tertentu. tetapi tidak cocok untuk pelajar dengan gaya belajar yang lain. Hal ini memang tidak bisa dipaksakan karena terkait dengan kemampuan tiap-tiap pengajar itu sendiri.

Para ahli memberikan beberapa pengertian gaya belajar. Pada dasarnya kemampuan seseorang untuk memahami dan menyerap pelajaran sudah pasti berbeda tingkatnya. Ada yang cepat, sedang, dan ada pula yang sangat lambat. Oleh karena itu, siswa seringkali harus menempuh cara berbeda untuk bisa memahami sebuah informasi atau pelajaran yang sama. Gaya belajar merupakan cara belajar yang khas bagi siswa (Winkel SJ, 2009).

Observasi dan wawancara awal penelitian ini disimpulkan beberapa permasalahan yang dialami di jurusan Multimedia SMK Negeri 1 Sukasada bahwa pencapaian kemampuan siswa terhadap pelajaran teknik pengambilan gambar bergerak masih belum maksimal. Kurang maksimalnya pencapaian kemampuan siswa tersebut disebabkan karena belum adanya media yang mampu memfasilitasi siswa dalam meningkatkan pencapaian kemampuan siswa. Berdasarkan data yang diperoleh dari guru mata pelajaran teknik pengambilan gambar bergerak diketahui bahwa $40 \%$ dari total keseluruhan siswa kelas XI Multimedia belum memenuhi kreteria ketuntasan minimal (KKM). Melihat jumlah siswa yang belum tuntas masih cukup banyak dalam pelajaran teknik pengambilan gambar bergerak maka akan menjadi permasalah dalam proses pembelajaran selanjutnya.

(Saputra, B. \& Buditjahjanto, 2017) menjelaskan bahwa pembelajaran berbasis personalisasi (personalized learning) adalah pembelajaran pribadi yang menyesuaikan pada setiap kekuatan, kebutuhan dan kepentingan siswa. Salah satu Pendekatan yang digunakan dalam mengembangkan personalisasi e-learning yaitu melalui pendekatan Felder Silverman Learning Style Model (FSLSM). (Hussein Ibrahim \& Hussein, 2015) menyatakan bahwa gaya belajar memegang peranan penting yang dapat menentukan hasil belajar peserta didik di dalam kelas.

Personalisasi juga dapat diartikan sebagai pembelajaran mandiri antar materi dan informasi atau profil pengguna dalam hal ini adalah siswa (Rahmat, 2018). Oleh karena itu, baik struktur maupun informasi mengenai siswa lebih dahulu dibutuhkan sebelum personalisasi dapat terjadi. Gaya belajar dianggap sebagai parameter yang penting untuk menentukan metode pembelajaran yang paling cocok untuk seorang pembelajar. Gaya belajar merupakan pendekatan dalam pembelajaran yang menekankan fakta bahwa individu-individu memiliki karakteristik dan preferensi berkaitan dengan cara menerima dan memproses informasi dengan cara-cara yang sangat berbeda. Ada berbagai teori yang memodelkan gaya belajar, salah satunya adalah teori gaya belajar Felder-Silverman.

FSLSM merupakan salah satu teori gaya belajar yang diusulkan oleh Felder dan Silverman pada tahun 1988 (Lakkah et al., 2017). Berdasarkan banyak hasil penelitian, FSLSM merupakan learning style yang paling sesuai untuk diaplikasikan dalam e-learning atau pembelajaran online lainnya (Toktarova, 2018). Secara jelas, teori FSLSM membedakan preferensi atau karakteristik siswa dalam menerima dan mengolah informasi 
ke dalam empat dimensi. Empat dimensi tersebut antara lain: (1) dimensi aktif/reflektif, (2) dimensi sensing/intuitive, (3) dimensi visual/verbal, dan (4) sekuensial/global. Dalam penelitian ini pembahasan mengenai FSLSM lebih di fokuskan pada dimensi visual/verbal.

Felder-Silverman menggunakan dimensi Input (visual/verbal), dan Understanding (sequential/global), detail dimensi dari gaya belajar Felder-Silverman ditampilkan pada Tabel 1.

Tabel 1. Dimensi Gaya Belajar Felder Silverman (Nasuha, 2015)

\begin{tabular}{cll}
\hline \multicolumn{1}{c}{ Dimensi } & \multicolumn{1}{c}{ Gaya Belajar } & \multicolumn{1}{c}{ Keterangan } \\
\hline Pemrosesan & $\begin{array}{l}\text { Active } \\
\text { Reflexive }\end{array}$ & $\begin{array}{l}\text { Bagaimana siswa memproses } \\
\text { informasi }\end{array}$ \\
Persepsi & $\begin{array}{l}\text { Sensitive } \\
\text { Intuitive }\end{array}$ & $\begin{array}{l}\text { Berkaitan dengan bagaimana } \\
\text { siswa melakukan persepsi } \\
\text { informasi }\end{array}$ \\
Input & Visual & Jenis inputan informasi seperti \\
& Verbal & apa yang mudah diterima siswa \\
Pemahaman & Sequential & Bagaimana siswa mencapai \\
& Global & pengertian \\
\hline
\end{tabular}

(Ahmadi \& Gilakjani, 2012) mengemukakan bahwa siswa secara umum memiliki tiga jenis gaya belajar yaitu visual, auditori dan kinestetik. Berdasarkan hal tersebut, dapat dikaji bahwa hasil belajar siswa dipengaruhi oleh faktor gaya belajar setiap siswa. Penelitian (Partiwi, 2016) tentang kecenderungan gaya belajar yang dimiliki siswa di SD Gugus VI Kecamatan Buleleng adalah 56,92\% siswa cenderung memiliki gaya belajar visual, 44,62\% siswa cenderung memiliki gaya belajar auditorial, dan 43,07\% siswa cenderung memiliki gaya belajar kinestetik. Hasil penelitian ini menyatakan bahwa terdapat kecenderungan gaya belajar siswa yang beragam dan kecenderungan gaya belajar yang beragam ini menjadi salah satu faktor yang mempengaruhi hasil belajar siswa.

Pada penelitian ini, dimensi gaya belajar yang menjadi fokus utama peneliti yaitu visual, dan verbal. Adapun tujuan dari pengembangan sistem personalisasi ini adalah memberikan inovasi dalam hal kenyamanan dan lebih jauh lagi mengenai peningkatan efektivitas dalam proses pembelajaran.

Berdasarkan permasalahan di atas peneliti memandang perlunya mengembangkan sebuah e-learning yang berorientasi pada gaya belajar (learning styles) yang berjudul "Pengembangan Sistem Personalisasi E-Learning Berorientasi Felder Silverman Learning Style Model Untuk Materi Teknik Pengambilan Gambar Bergerak Terhadap Hasil Belajar Siswa di SMK Negeri 1 Sukasada".

\section{METODE PENELITIAN}

Jenis penelitian ini adalah penelitian pengembangan. Desain penelitian yang digunakan adalah desain pengembangan ADDIE. Subjek penelitian ini adalah 23 orang siswa kelas XI Multimedia di SMK Negeri 1 Sukasada, satu orang guru mata pelajaran teknik pengambilan gambar, para ahli yang terdiri atas satu ahli isi, satu ahli media dan satu ahli desain pembelajaran, siswa dalam uji coba perorangan sebanyak 3 orang dan siswa dalam uji coba kelompok kecil sebanyak 9 orang. Objek penelitian ini adalah tanggapan dari para siswa, guru, ahli isi, ahli media, ahli desain, siswa perorangan, siswa kelompok kecil, uji pretest dan posttest mengenai produk yang dikembangkan.

Jenis data yang diperoleh ada tiga yaitu: (1) data hasil review ahli isi, ahli media dan ahli desain pembelajaran; (2) data tanggapan siswa pada uji coba perorangan, kelompok 
kecil; (3) nilai pretest dan posttest untuk hasil belajar teknik pengambilan gambar. Seluruh data yang diperoleh, dikelompokkan menurut sifatnya menjadi dua, yaitu. data kualitatif dan data kuantitatif. Terdapat dua instrumen yang digunakan untuk mendapatkan data tentang kualitas produk yang dikembangkan yaitu, kuisioner/angket dan tes hasil belajar teknik pengambilan gambar.

Penelitian pengembangan ini menggunakan tiga jenis teknik analisis data, yaitu: analisis deskriptif kualitatif, analisis deskriptif kuantitatif, dan analisis statistik inferensial uji- $t$.

\section{HASIL DAN PEMBAHASAN}

\section{HASIL}

Berdasarkan pada analisis data yang telah dikumpulkan dalam penelitian ini, telah dihasilkan produk media pembelajaran berupa e-learning berorientasi FSLSM pada mata pelajaran teknik pengambilan gambar untuk siswa kelas XI Multimedia di SMK Negeri 1 Sukasada. Produk yang dihasilkan dirancang berdasarkan diagram alur yang disajikan pada Gambar 2.

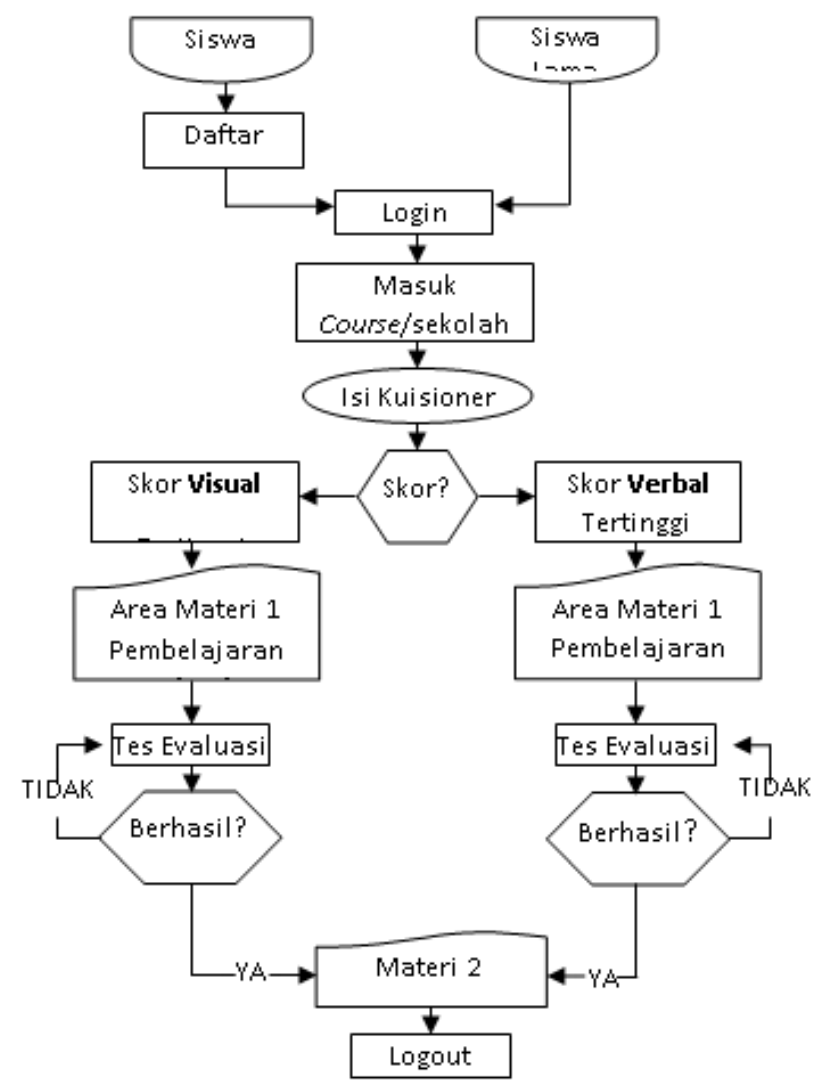

Gambar 2. Diagram alur e-learning berorientasi FSLSM.

akses pengguna, dan memasukkan konten pelajaran pada Moodle. Dalam e-learning berorientasi FSLSM ini terdapat tiga pengguna utama dalam proses pembelajaran yaitu administrator, guru, dan siswa. Berdasarkan pada rancangan diagram alur kemudian diimplementasikan kedalam tampilan antarmuka e-learning berorientasi FSLSM. Tampilan antarmuka e-learning disajikan pada Gambar berikut 


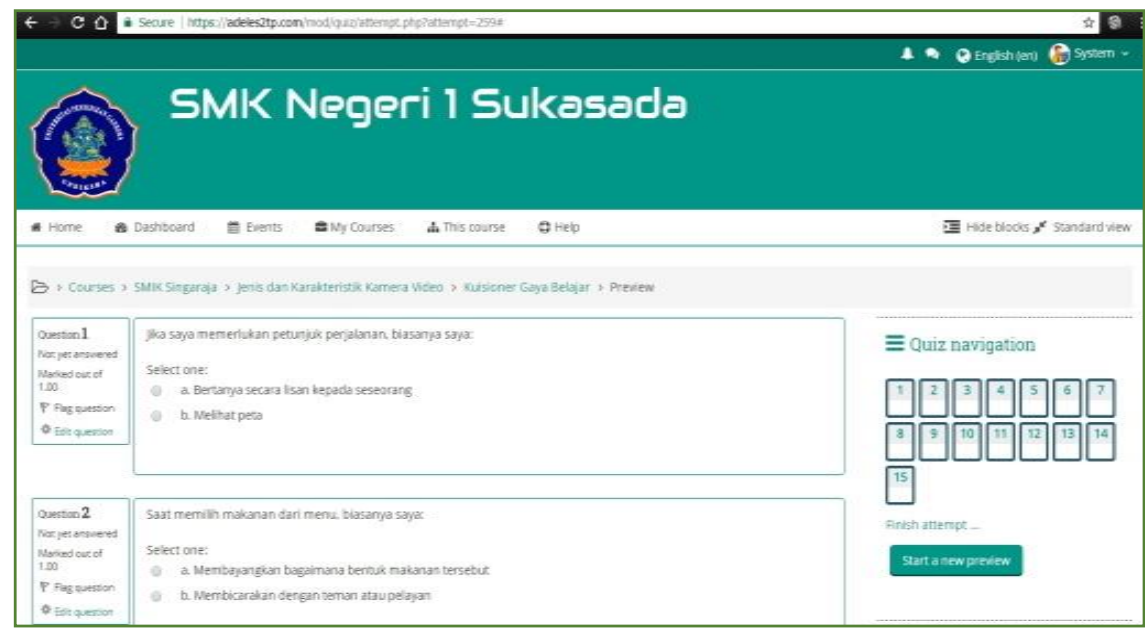

Gambar 3. Tampilan Kuisioner/angket Gaya Belajar

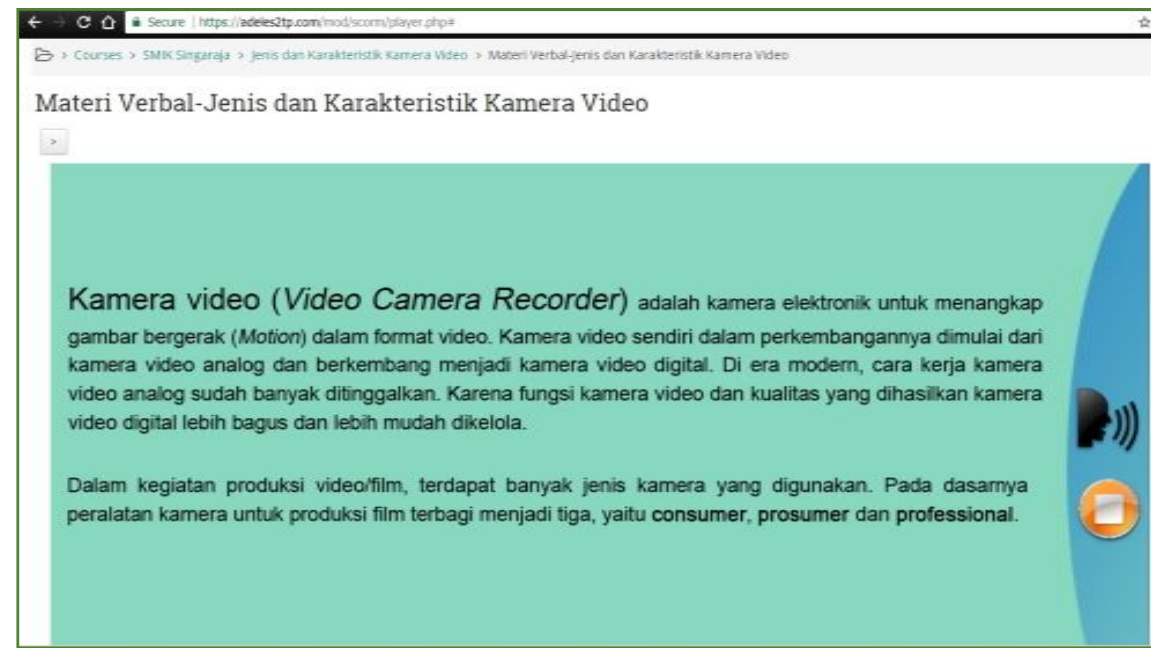

Gambar 4. Tampilan Materi yang di Sesuikan Dengan Hasil Kuisioner Gaya Belajar

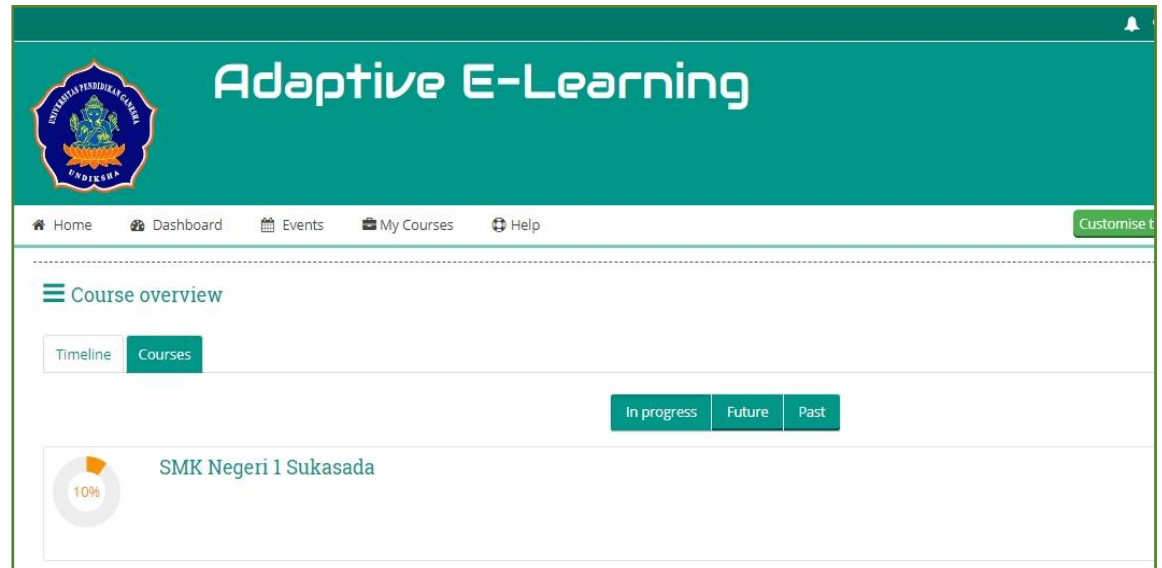

Gambar 5. Tampilan Progress atau Pencapaian Selama Pembelajaran Menggunakan Elearning 
Setelah melakukan perhitungan dan tinjauan terhadap hasil pengujian oleh dua orang ahli media maka dapat diketahui bahwa hasil angket e-learning menunjukkan tingkat pencapaian "SESUAI" dan layak untuk dilanjutkan. Berdasarkan hasil penilaian dari ahli desain pembelajaran maka dapat disimpulkan bahwa tingkat pencapaian dari e-learning adalah "SESUAI" dan layak untuk dilanjutkan. Hasil uji coba siswa perorangan diperoleh presentase sebesar 79,33\% dengan kategori baik. Hasil uji coba kelompok kecil diperoleh presentase sebesar 86,50\% dengan kategori baik. Uji lapangan diperoleh presentase sebesar $79,70 \%$ dengan kategori baik. Hasil uji pretest dan posttest diperoleh rata-rata pretest lebih kecil daripada posttest $65,26<81,09$. harga thitung dibandingkan dengan harga t pada tabel dengan $\mathrm{db}=\mathrm{n} 1+\mathrm{n} 2-2=23+23-2=44$. Harga ttabel untuk db 44 dan dengan taraf signifikansi $5 \%(\alpha=0,05)$ adalah 2,01. Dengan demikian, harga thitung yaitu 2,34 lebih besar daripada harga ttabel sehingga $\mathrm{H} 0$ ditolak dan $\mathrm{H} 1$ diterima. Ini berarti bahwa terdapat perbedaan yang signifikan hasil belajar Teknik Pengambilan Gambar Bergerak kelas XI semester genap, antara sebelum dan sesudah menggunakan e-learning berorientasi FSLSM, yang berarti pula bahwa media yang dihasilkan dalam penelitian ini efektif untuk digunakan dalam proses pembelajaran.

\section{PEMBAHASAN}

Pengembangan system personalisasi e-learning berorientasi FSLSM memiliki tujuan untuk membantu siswa agar lebih mudah memahami materi pelajaran sesuai dengan karakteristik siswa, serta penambahan sumber belajar, media pembelajaran, dan diharapkan dapat meningkatkan hasil belajar selama proses belajar mengajar di kelas.

Dalam penelitian ini produk e-learning berorientasi FSLSM telah dirancang dengan model ADDIE. Model ini terdiri atas lima tahapan, yaitu: (1) analisis (analyze), (2) perancangan (design), (3) pengembangan (development), (4) implementasi (implementasi), (5) evaluasi (evaluation). Setelah ditentukan tahapan model pengembangan yang akan digunakan, maka dirancang tampilan awal atau sitemap dalam perancangan struktur menu dan konten yang akan ditampilkan kepada siswa. Pada tahap ini dikembangkan konten yang akan disajikan ke pengguna sesuai dengan hasil angket atau kuisioner gaya belajar yang dijawab setelah pengguna berhasil login ke halaman beranda elearning. Adapun jenis konten yang disediakan yaitu konten gaya belajar Verbal, dan konten gaya belajar Visual.

Adapun hasil perancangan struktur menu (sitemap) e-learning berorientasi FSLSM pada aplikasi Moodle yaitu sebagai berikut.

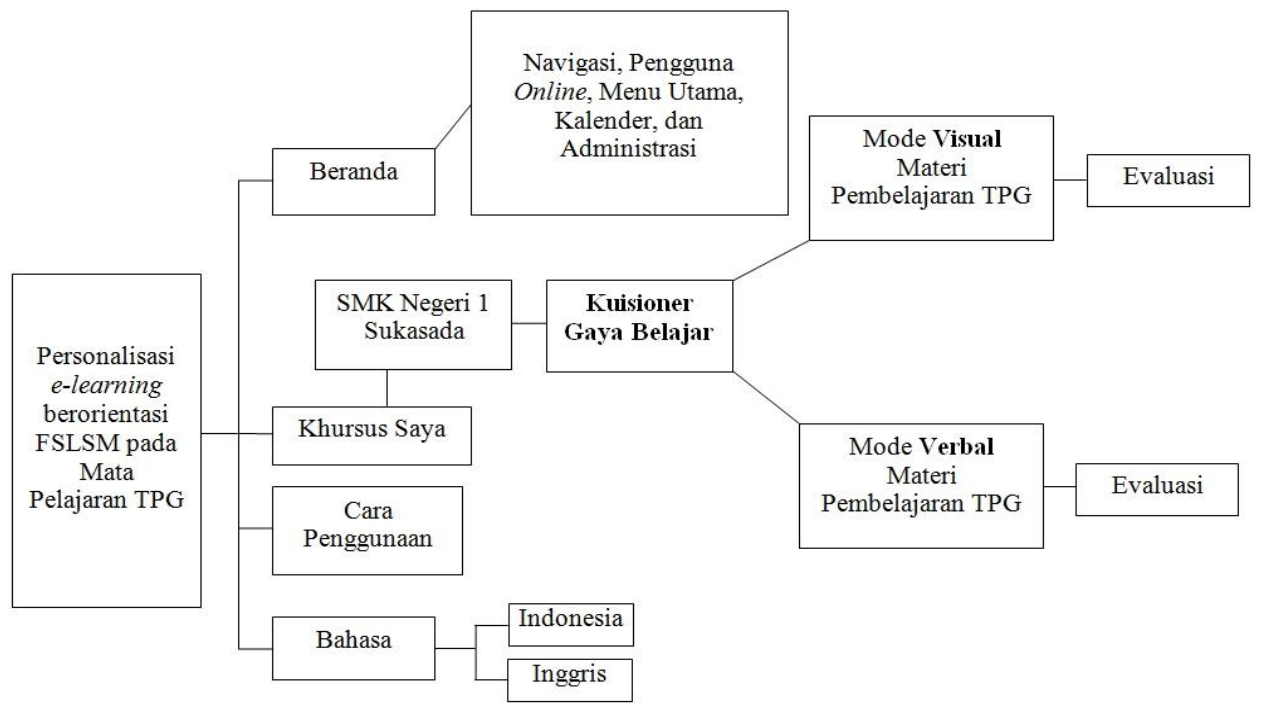

Gambar 6. Sitemap Pengembangan E-Learning Berorientasi FSLSM Pembelajaran TPG. 
Setelah melalui tahapan pengembangan sistem. Sistem kemudian diujicobakan ke ahli dan kelompok sampel yang telah dipilih. Adapun antarmuka sistem personalisasi $e$ learning yang dikembangkan dapat dilihat pada Gambar 7 berikut.

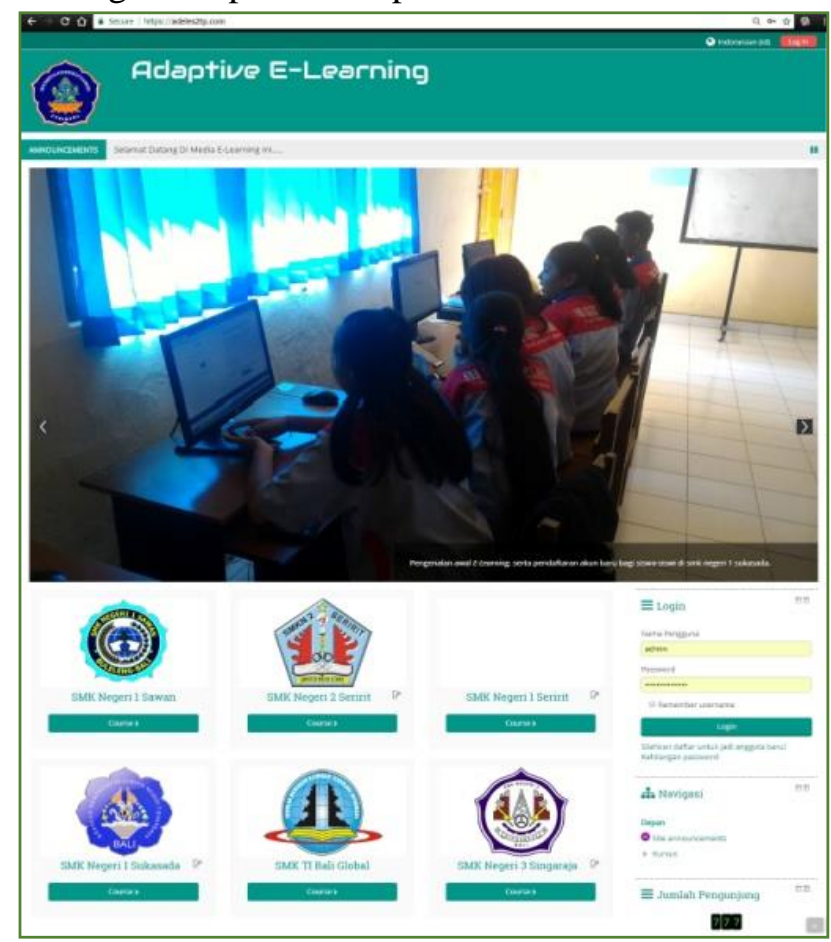

Gambar 7. Tampilan Antarmuka Awal E-Learning

Selanjutnya penilaian terhadap sistem yang dilakukan oleh para ahli. Dalam hal ini, penilaian sistem melibatkan 3 orang dosen yang ahli dalam bidang desain pembelajaran dan e-learning. Adapun hasil penilaian dari para ahli dapat dilihat pada Tabel 2 berikut.

Tabel 2. Hasil Penilaian Para Ahli

\begin{tabular}{ccc}
\hline No & Aspek & Kelayakan \\
\hline $\mathbf{1}$ & Isi Pembelajaran & Sesuai \\
$\mathbf{2}$ & Desain Pembelajaran & Sesuai \\
$\mathbf{3}$ & Media Pembelajaran & Sesuai \\
\hline
\end{tabular}

Data yang diperoleh melalui hasil uji coba perorangan, kualitas e-learning berorientasi FSLSM berada pada kualifikasi baik. Dalam uji coba perorangan, kriteria "isi materi dalam e-learning mampu menarik minat siswa belajar" memperoleh skor paling tinggi. Hal itu dikarenakan konten e-learning dikemas sesuai dengan karakteristik gaya belajar siswa, sehingga siswa lebih mudah memahami materi pelajaran. Hal ini sesuai dengan pendapat dari (Mite et al., 2016) yaitu "setiap orang lebih cenderung untuk menggunakan satu gaya belajar saja dan semua gaya belajar yang dimiliki mempunyai peluang yang sama untuk memperoleh hasil belajar yang baik, sehingga dalam perancangan konten e-learning akan lebih memperhatikan dominansi gaya belajar siswa".

Berdasarkan data-data yang diperoleh melalui uji coba kelompok kecil, kualitas e-learning pada kualifikasi baik. Dalam uji coba kelompok kecil, kriteria "penggunaan e-learning membuat proses belajar menjadi lebih mudah" dalam e-learning memperoleh skor paling tinggi. Hal itu dikarenakan setiap tahapan belajar siswa pada e-learning mampu menampilkan progress atau pencapaian siswa selama mengikuti kegiatan belajar. 
Setelah uji coba kelompok kecil selesai dilanjutkan dengan uji lapangan yang dilakukan oleh dua puluh tiga orang siswa kelas XI Multimedia di SMK Negeri 1 Sukasada. Dari hasil angket uji coba diperoleh, rata-rata penilaian keseluruhan responden uji lapangan adalah $79,70 \%$. Jika dikonversikan ke dalam tabel konversi tingkat pencapaian termasuk dalam kategori baik dan tidak perlu revisi pada e-learning. Berdasarkan temuan di lapangan, penggunaan e-learning dalam proses kegiatan belajar mengajar di kelas dapat membantu siswa memahami materi lebih cepat dikarenakan siswa mampu memahami materi sesuai dengan bentuk gaya belajar siswa, dan meningkatkan interaksi antar guru dan siswa. Melalui isi materi yang disajikan dalam bentuk teks, gambar, audio dan video dalam e-learning siswa lebih mudah memahami materi dan sangat membantu dalam pengerjaan tugas.

Dalam penelitian ini juga mampu meningkatkan prestasi belajar siswa dengan hasil yang telah dicapai seseorang dalam melakukan kegiatan. (Gagné et al., 2010) menyatakan bahwa Prestasi Belajar dibedakan menjadi lima aspek, yaitu : kemampuan intelektual, strategi kognitif, informasi verbal, sikap dan keterampilan. Menurut Bloom dalam (Suharsimi, 2013), bahwa hasil belajar dibedakan menjadi tiga aspek yaitu kognitif, afektif dan psikomotorik.

Dalam penelitian ini prestasi belajar dapat ditentukan pada tahap evaluasi belajar dimana peneliti bisa mengetahui tingkat prestasi yang dicapai siswa baik prestasi tinggi, sedang, maupun rendah (Syafi'i, 2018).

Hasil penelitian sistem personalisasi e-learning berorientasi FSLSM pada mata pelajaran TPG ini sejalan dengan penelitian (Marzoan, 2016) tentang Gaya Belajar Felder Silvermen dan Hasil Belajar Sains di Sekolah Dasar yaitu sama-sama memperoleh penilaian layak dan mendapat respon sangat positif. Dalam implementasinya pengembangan e-learning (Ziaurrahman \& Surjono, 2018) dan penelitian ini dikemas dalam bentuk mobile learning dengan model adaptif, yang mampu memberikan kemudahan dalam mengakses sumber belajar serta meberikan tingkat kemudahan pemahaman informasi yang diperoleh sesuai dengan kecenderungan gaya belajar yang dimiliki.

Senada dengan itu hasil penelitian (Ahmed et al., 2017), dalam penelitiannya berhasil mengembangkan sistem yang dapat menjembatani pelajar dengan pebelajar dengan memperhatikan gaya belajar. Respon dari pengguna sistem berkategori positif, dan mampu meningkatkan efektivitas belajar pelajar. Hasil penelitian ini dirasa penting untuk pengembangan e-learning berorientasi FSLSM karena dengan memperhatikan gaya belajar dalam pengembangan media pembelajaran dapat meningkatkan efektivitas belajar di dalam kelas.

Melalui penerapan e-learning berorientasi FSLSM pada pelajaran TPG ini diharapkan dapat membantu guru selama proses pembelajaran dan masalah selama proses pembelajaran terkait sumber belajar mampu teratasi, intensitas belajar siswa meningkat, dan membantu siswa menjadi lebih aktif dalam proses belajar mengajar secara mandiri maupun berkelompok.

\section{SIMPULAN}

Pembelajaran e-learning menuju adaptive learning. Model ini merupakan sebuah framework pembelajaran online yang memberikan keleluasaan kepada pengguna (learner) untuk mengakses materi sesuai dengan kemampuannya masing-masing (Sundayana, 2018). Model ini telah menyediakan fitur-fitur dimana penyedia materi (content provider) untuk melakukan setting terhadap instrumen awal (pre-tes), batas minimal pemahaman dari masing-masing materi, serta relasi antara materi satu dengan materi lainnya. Personalisasi e-learning dapat memberikan kenyamanan lebih dalam proses pembelajaran menggunakan e-learning. Personalisasi e-learning dapat dilaksanakan tidak hanya di tingkat menengah kejuruan (SMK) namun di tingkat perguruan tinggi. Penelitian ini membuktikan bahwa 
personalisasi e-learning yang menggunakan adopsi konsep visual/verbal dan kinestetik dari FSLSM mendapatkan sambutan yang baik dari penggunanya.

\section{DAFTAR PUSTAKA}

Agustini, K. (2017). The Adaptive Elearning System Design : Student Learning Style Trend Analysis. https://doi.org/10.2991/icirad-17.2017.10

Ahmadi, M. R., \& Gilakjani, A. P. (2012). Reciprocal teaching strategies and their impacts on English reading comprehension. Theory and Practice in Language Studies. https://doi.org/10.4304/tpls.2.10.2053-2060

Ahmed, M., Hussain, S., \& Bagram, M. (2017). E-Content Presentation based on Learning Styles. University of Engineering and Technology Taxila. Technical Journal.

Cronin, M. (2012). Translation in the digital age. In Translation in the Digital Age. https://doi.org/10.4324/9780203073599

Gagné, R., Ateş, A., Doktora, E., Üniversitesi, E., Fakültesi, E., Ve, B., Teknolojileri, Ö., Bölümü, E., \& Görevlisi, Ö. (2010). The Conditions of Learning and Theory of Instruction. Elementary Education Online. https://doi.org/10.1016/00224405(79)90058-X

Hussein Ibrahim, R., \& Hussein, D. A. (2015). Assessment of visual, auditory, and kinesthetic learning style among undergraduate nursing students. International Journal of Advanced Nursing Studies. https://doi.org/10.14419/ijans.v5i1.5124

Lakkah, S. El, Alimam, M. A., \& Seghiouer, H. (2017). Adaptive e-learning system based on learning style and ant colony optimization. 2017 Intelligent Systems and Computer Vision, ISCV 2017. https://doi.org/10.1109/ISACV.2017.8054963

Marzoan. (2016). Gaya Belajar Felder-Silverman dan Hasil Belajar Sains di Sekolah Dasar ( SD ). Seminar Asean 2th Psychology and Hmanity, Forum Psikologi UMM. https://doi.org/10.1007/s00455-007-9091-6

Mite, Y., Corebima, A., \& Syamsuri, I. (2016). Hubungan Antara Gaya Belajar Dengan Hasil Belajar Siswa SMA Katolik Santa Maria Malang Berbasis Skor Terkoreksi Dalam Pembelajaran Biologi Melalui Pembelajaran Group Investigation (GI) Tahun Ajaran 2015/2016. Jurnal Pendidikan - Teori, Penelitian, Dan Pengembangan. https://doi.org/10.17977/jp.v1i5.6262

Mothukuri, U. K., Reddy, B. V., Reddy, P. N., Gutti, S., Mandula, K., Parupalli, R., Murty, C. H. A. S., \& Magesh, E. (2017). Improvisation of learning experience using learning analytics in eLearning. Proceedings - 2017 5th National Conference on E-Learning and E-Learning Technologies, ELELTECH 2017. https://doi.org/10.1109/ELELTECH.2017.8074995

Nasuha, A. M. I. (2015). Pengembangan Personalisasi Gaya Belajar pada E-learning dengan Menggunakan Felder Silverman Learning Style Model untuk Sekolah Menengah Kejuruan (SMK). Jurnal Nasional Pendidikan Teknik Informatika, Volume https://www.researchgate.net/publication/334240183_Pengembangan_Personalisasi _Gaya_Belajar_pada_Elearning_dengan_Menggunakan_Felder_Silverman_Learning_Style_Model_untuk_ Sekolah_Menengah_Kejuruan_SMK

Rahmat, H. (2018). Hubungan Gaya Mengajar Guru Dengan Motivasi Belajar Siswa Pada 
Mata Pelajaran Bahasa Inggris. Jurnal Jurusan PGMI, Vol.10 No. https://journal.uinmataram.ac.id/index.php/elmidad/article/download/775/436

Saputra, B. \& Buditjahjanto, I. G. P. A. (2017). Pengembangan media pembelajaran elearning berbasis website Pada kompetensi dasar menerapkan konsep dasar-dasar teknik digital Di smk negeri 2 lamongan. Jurnal Pendidikan Teknik Elektro., 6(3). http://jurnalmahasiswa.unesa.ac.id/article/24923/44/ article.pdf

Slavin, R. E. (1977). A student team approach to teaching adolescents with special emotional and behavioral needs. Psychology in the Schools. https://doi.org/10.1002/1520-6807(197701)14:1<77::AIDPITS2310140116>3.0.CO;2-C

Suharsimi;, A. (2013). Dasar-Dasar Evaluasi Pendidikan. In Jakarta: Bumi Aksara.

Sundayana, R. (2018). Kaitan antara Gaya Belajar, Kemandirian Belajar, dan Kemampuan Pemecahan Masalah Siswa SMP dalam Pelajaran Matematika. Mosharafa: Jurnal Pendidikan Matematika. https://doi.org/10.31980/mosharafa.v5i2.262

Syafi'i, A. (2018). Studi Tentang Prestasi Belajar Siswa Dalam Berbagai Aspek Dan Faktor Yang Mempengaruhi. Jurnal Komunikasi Pendidikan, Vol.2 No.2. http://journal.univetbantara.ac.id/index.php/komdik/article/download/114/102

Toktarova, V. I. (2018). Models of the learning styles within the adaptive system of mathematical training of students. Issues and Trends in Interdisciplinary Behavior and Social Science - Proceedings of the 6th International Congress on Interdisciplinary Behavior and Social Sciences, ICIBSoS 2017. https://doi.org/10.1201/9781315148700-39

Winkel SJ, W. . (2009). Psikologi Pengajaran. Gramedia.

Ziaurrahman, Z., \& Surjono, H. D. (2018). Pengembangan e-learning adaptif pada mata pelajaran Pendidikan Agama Islam untuk kelas X SMA. Jurnal Inovasi Teknologi Pendidikan. https://doi.org/10.21831/jitp.v4i2.10458 